\title{
Measuring Student Satisfaction with Performance Enhancement Activities: Evidence from Business Education
}

\author{
Al-Rafai Adnan, Al-Fahad Mohamed, Arafa Tarek, Son Mun, and Hamdy Hosny
}

\begin{abstract}
The college of business Administration (CBA) at Kuwait University was initially accredited in 2005. Accreditation was maintained in 2010 and is preparing for the 2015 review. Direct and Indirect measurements of learning outcomes are part of AACSB accreditation standards. This study is devoted to the latter kind. A structured questionnaire, based on the service package concept, is used to measure overall student satisfaction and satisfaction with CBA's delivered services. Structural equation modeling is used to fit the data to a proposed student satisfaction model and investigate the total effect that the academic factors (exogenous variables) have on overall student satisfaction (outcome variable) and the role of the professional student clubs as mediator between these two sets of variables. The study also discusses the effect of demographic characteristics on research variables and identifies delivered services in need of improvement. The added value to the literature on measuring business school satisfaction is in the discovery of the vital role that student clubs can play in assisting administration in achieving a school's learning outcomes and in increasing student satisfaction.
\end{abstract}

Index Terms-Business college education, confirmatory factor analysis, student satisfaction, survey design and analysis.

\section{INTRODUCTION}

The College of Business Administration (CBA) at Kuwait University was established in 1995 to replace the College of Business, Economics, and Political Science founded in 1967. CBA's mission and vision focus on the delivery of quality business education. To fulfill this ambition, accreditation from the Association to Advance Collegiate Schools of Business (AASCB), a renowned international accreditation body for business education, was sought in 2002. AACSB accreditation of a school confirms its commitment to quality and continuous improvement and "is the hallmark of excellence in management education [1]. It is a recognition that the structures and processes necessary to meet the school's mission, objectives and learning goals in addition to continuous performance improvement activities are in place

Manuscript received March 12, 2015; revised June 23, 2015.

Al-Rafai Adnan and Hamdy Hosny are with the Department of Quantitative Methods and Information Systems, Kuwait University, Kuwait (e-mail: alrefai730@gmail.com).

Al-Fahad Mohamed is with the Department of Public Administration, Kuwait University, Kuwait (e-mail: alfahad@cba.edu.kw).

Arafa Tarek is with the Department of Management \& Marketing, Kuwait University, Kuwait (e-mail: tareq@cba.edu.kw).

Son Mun is with the Department of Mathematics and Statistics, University of Vermont 16 Colchester Avenue, Burlington, VT 05401 , United States (e-mail: mson@uvm.edu).
[2]. Accreditation by AACSB International was granted in 2005 and was maintained in 2010. The school is currently preparing for the 2015 accreditation maintenance review.

First time eligibility for AACSB accreditation and its on-going maintenance is granted to a business school as a result of demonstrating the fulfillment of up to twenty one standards that are classified under three major areas: 1) Strategic Management; 2) Business School Participants and 3) Assurance of Learning [3]. Assurance of Learning requires the presentation of proof that the expected accomplishments of the school's graduates (learning goals) have been defined and that those goals have been achieved. AACSB considers student learning the central activity of higher education [4]. Proof of fulfillment of the Assurance of Learning standards includes the general and management specific learning goals to be achieved and the various measures used to demonstrate that student performance meets these learning goals. According to AACSB, a school can use direct measures and/or indirect measures to demonstrate Assurance of Learning. Direct measures include course-embedded measurement (e.g., a capstone business-strategy course exam) and stand-alone testing of performance (e.g., a senior project). Indirect measures collect information on perceptions of student achievement (e.g., surveying students about their satisfaction with the performance enhancement activities provided by the school and/or surveying alumni about how well the school prepared them for the working world) [4].

This study involves indirect measures for assessing Assurance of Learning. It measures undergraduate student satisfaction with CBA's efforts to optimize student performance and preparation for post-graduation success professionally, socially, and personally. Our study measures student satisfaction with a questionnaire modeled after the work of Douglas, Douglas, and Barnes [5]. Their feedback questionnaire measured student satisfaction at Liverpool John Moores University's Faculty of Business and Law. The original questionnaire was designed around the concept of the Service-Product Bundle (also known as the Service Package, see Section II for a complete definition). Douglas and colleagues sought students' opinions about all aspects of academic life asking only for their perception of the quality of the services offered but not for their expectations. Students were also asked to indicate the importance of each service. In our study, the questionnaire was also designed around the concept of the service package. The focus is on student satisfaction with the main services influencing learning outcomes but does not include student perceptions of the importance of the services.

The study has four goals: 1) collect data regarding student 
satisfaction with the main services (key factors) making up the educational learning experience, the department of their major, and the school in general. Analyze the data and provide feedback to the Dean of CBA and to the AACSB accreditation review team. 2) Reveal any services with which students are dissatisfied. 3) Determine the effect of student gender, year of study, major, and general grade point average (GPA) on satisfaction with the services offered. 4) Investigate the inter-relationships between overall student satisfaction and the six factors meant to assure learning at CBA (see Section 3) to confirm our proposed model representing student satisfaction. Factor analysis and structural equation modeling were used through SPSS and LISREL software to identify which factors were directly and indirectly influencing the outcome of overall student satisfaction, to assess fit, and validate the proposed model.

\section{The OUtPut OF SERVICE ORGANIZATIONS}

Rust and Oliver [6] suggest that practically all organizations, including institutions of higher education, have both a good- and a service-orientation and that the ratio of goods to services will vary depending on the type of organization. This ratio of goods to services is referred to as the Service Package [7], [8]. A Service Package is also known as the Service-Product Bundle [9] that is, a bundle of goods and services, or a Service Package Mix (i.e., a mixture of goods and services offered [10]). Fig. 1 summarizes the nature of the Service Package which was used as the underlying framework in constructing the questionnaire for this study.

The output of a service organization (the Service Package) consists of two parts: 1) what is being delivered (physical items and/or pure services) and 2) how it is being delivered (intangible service elements). What is being delivered can consist of up to six elements: a) Items which are purchased by the customer (e.g., text books, note books, lecture notes, cafeteria meals, etc.) and/or pure services purchased by the customer (e.g., lectures, tutorials, training courses, computer and internet services, etc.); b) Items which are supplied free of charge (e.g., college freshmen student guide, class handouts, free food in student club events, etc.) and/or pure services supplied free of charge (e.g., on-line registration, academic advising, career planning, medical services, office hours, Wi-Fi service, talks by guest speakers, etc.); c) Physical items owned by the customer that are changed in the course of the service process (e.g., professional proof-reading/correcting a report, typing a term paper, binding a typed project, etc.); d) Physical or geographical changes (i.e., intellectual, emotional, spiritual, and biologically physical) done to the customer (e.g., knowledge and skills development from lectures, becoming motivated after attending a speech, maturity growth from college experience, losing weight through sports activities, using the campus bus to get around campus, etc.); e) Physical items needed to carry out the operations of delivering the service package that are used by the customer (e.g., class syllabus, chalk and white board pens, computers and printers in computer labs, data shows in lecture halls for Power Point presentations, etc.); f) Servicescape, the external and internal physical environment of the service organization that is designed with an appearance and feel that is in harmony with the service concept and influences the behavior of both customers and employees (Fitzsimmons \& Fitzsimmons, 2008). This includes: facility layout, spaciousness, style and décor, furnishings, equipment, service personnel uniforms, landscaping, parking, and ambient conditions (i.e., sights, lighting, sounds, weather, and aromas that are integral to the service theme). The layout and interior design of lecture halls and computer labs, quality and comfort of furnishing in student lounges and lecture halls, overhead projectors, white boards, cafeteria personnel uniforms, cooling/heating of lecture halls, professional appearance of buildings, grounds, and parking lots, are all parts of the Services cape.

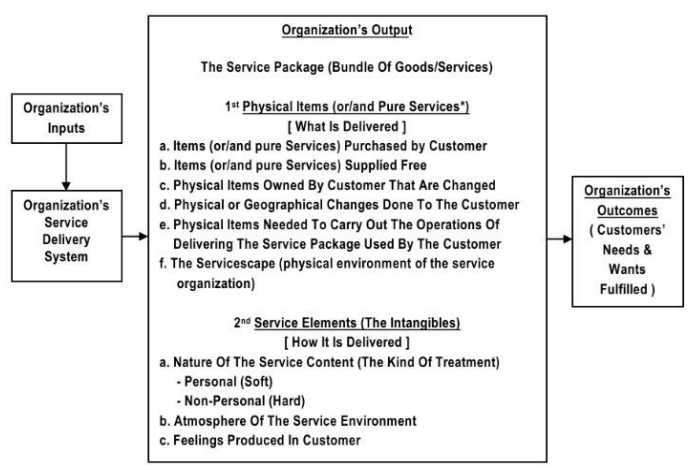

Fig. 1. The service package (the output) of a service oriented organization.

The Fig. 1 shows that the output of a service organization consists of what is being delivered and how it is being delivered which then leads to outcome fulfillment.

A pure service is an intangible act or performance that a service provider offers a customer that does not result in the ownership of anything and is meant to fulfill the customer's needs and wants as expected [5].

Intangibles associated with the service package include: a) The nature of the service contact (i.e., the kind of treatment typically received from professors, TAs, administration staff, etc.), which may be personal, soft, friendly, respectful, etc., or impersonal, hard, cold, and formal; b) The atmosphere of the service environment resulting from ambient conditions, overall cleanliness, and the nature of the service contact (e.g., friendly, professional, fair, and student-centered); c) The feelings produced in the customers (importance, intelligence, ambition, self-esteem, etc.) including those feelings and opinions generated toward the organization (knowledgeable, up-to-date, devoted, and well-prepared professors, consistently high teaching quality, reasonable workload, genuine interest in student well-being, pride).

According to Douglas and colleagues (2006), "the concept of the service-product bundle is a valid and reliable tool for the design of a satisfaction survey." The service package concept guided the creation of questionnaire instruments in our study. Many of the instruments served more than one service package element and all of the elements were considered except for 1c, 1e, and 1f (see Fig. 1) which related to supporting services, operating items, and the services cape of the college. It was not our intention in this study to cover all aspects of campus life, rather the focus is on the main factors that assure the achievement of CBA's learning goals. Therefore, the structured questionnaire did not seek students' opinion about other CBA services (e.g., on-campus 
transportation, catering facilities, medical services, sports facilities, etc.) despite the literature indicating that those services influence student satisfaction [5], [11], [12].

\section{CONSTRUCTS DEFINED}

We present in the following paragraphs an explanation of each of the constructs of the proposed student satisfaction model depicted in Fig. 2, Section IV.

\section{A. Exogenous Variables}

\section{1) Academic performance satisfaction}

This construct concerns the satisfaction of CBA students with delivered academic performance. The level of student satisfaction from academic performance depends greatly on the extent to which they believe it will assist them in becoming successful in their personal and professional lives. Business school professors play the most important role in fulfilling this expectation by designing and effectively teaching up-to-date curriculums that introduce ethical issues, involve team work activities, encourage class involvement, and fulfill market requirements. Content delivery should include the human touch and professors need to be respectful and have a positive attitude towards their students. The establishment of friendly, mentoring relationships help students learns and advance intellectually and personally, and inspire them to develop new skills and become life-long learners. Furthermore, professors need to understand the importance of setting an example for their students by quickly returning assignments, quizzes and exams, by punctually showing up to their lectures and office hours, and effectively using these two activities to produce learning outcomes, see [5], [11], [13]-[17].

Many scholars believe that academic performance leads to student satisfaction in business schools. For example, Abbasi, Malik, Chaudhry, \& Imdadullah [13]; state that "faculty continues to be the most significant influence on student experience and satisfaction in universities." Letcher and Neves [15] believe that academic performance is one of the most important determinants of student satisfaction. Seng and Ling [11] mention that staff who demonstrate a genuine interest in the needs and progress of their students will increase student satisfaction.

\section{2) Teaching assistance (TA) satisfaction}

This construct concerns student satisfaction with teaching assistants' (TAs) role in supporting the educational learning process. Satisfaction with TAs performance will depend on: whether they help produce a positive academic climate that encourages student learning and enhances performance (e.g., whether they are prepared, deliver the subject matter with quality, return graded assignments in a timely way, respect and use office hours wisely, etc.; Maddox \& Nicholson, 2008); whether there are enough TAs available who demonstrate caring and concern for students (e.g., are empathetic, treat students as adults, listen, are friendly, etc.; see [12], [13], [18].

\section{3) Computer labs, dealing room satisfaction}

This construct is about student satisfaction with computer services and with both the capacity and operating hours of the computer labs. A number of researchers (see for example, [14], [16], [17], [19]) have confirmed that with the appropriate number of well-equipped computer labs and technical support, student satisfaction at business schools is greatly enhanced. The Computer Center at CBA supervises and maintains six computer labs consisting of over 200 computers and laser printers, provides on-demand technical assistance and training to students, provides all lecture halls, offices, and student clubs with high-speed internet, oversees the financial dealing rooms, provides $\mathrm{Wi}-\mathrm{Fi}$ service to the campus, and maintains classroom technology installed in each lecture hall.

\section{4) Registration process satisfaction}

This construct concentrates on student satisfaction with the class registration process. An efficient, user-friendly on-line registration system that offers a large variety of courses at various times to meet student demand should lead to student satisfaction. Efficient systems enable students to follow preplanned curricula and graduate on time [15]. The Orientation and Guidance Office at CBA overlooks registration and have other responsibilities including student affairs, the Dean's List Club, and the Activities and Programs Unit. The office prepares the master semester class schedules, supports honor students and their activities, solves student problems, and provides academic advising.

5) Training and student exchange programs satisfaction

This construct relates to student satisfaction with CBA's efforts to develop student character, personal and working-life skills through on-going training programs, internship, and activities with successful alumni. These programs are supervised by the Office of Student Training and Alumni (OSTA).OSTA is also very active in career planning and job placement services (e.g., job fairs, C.V. writing, bond-building activities with the market, etc.).Additionally, this construct includes the satisfaction with the international Student Exchange Program (SEP) that is conducted with overseas accredited business schools. Seng and Ling [11] encourage business schools to offer opportunities for their students to explore the real world in order to build self-confidence. This is currently being done at CBA through summer internships and the SEP.

\section{B. Mediating Variable: Professional Student Clubs, Satisfaction}

This construct is about the satisfaction of CBA students with student clubs. There are nine professional student clubs at CBA. The clubs have become very influential over the years and the focal point for extracurricular activities for students. Working closely with the Dean, department heads, the Orientation and Guidance Office, and OSTA, the clubs plan events designed to enhance student learning, as well as social, academic, and professional development. The clubs also help students decide on their field of focus by holding awareness activities of the various majors offered at CBA. In addition, newcomers receive support and guidance from senior students to help them excel in their chosen field of study and better handle academic stress. Furthermore, through field trips and invited speakers, the clubs expose 
students to key figures from leading organizations, helping to expand their professional network and better understand both their majors and how they are applied in the working world. Finally, the clubs play a large role in strengthening student identity with the school through frequent on-campus social activities.

We expect, based on the literature, that involvement in these extracurricular professional student clubs will lead to student satisfaction. Seng and Ling [11], mention that the students who participate in student organizations, interacting with faculty members and other students are more likely to have a higher level of satisfaction than those who do not. Thomas [14] found that the second most important factor driving student satisfaction was social networking with peers and close working relationships with other students.

\section{Outcome Variable: Overall Student Satisfaction}

The literature is rich with statements supporting the contention that student perception of service quality in a business school is the main determinant of student satisfaction and that the higher the levels of perceived quality, the higher the levels of student satisfaction. Perceived service quality in our research is defined as the student's perception of whether the technical and functional quality dimensions of all the school's outputs meet or exceed expectations. The technical dimension refers to the first part of the service package, what is delivered, while the functional dimension refers to the second part, how it is delivered (see [11], [13], [19]-[23]).

Out of simplicity, we assume that the student is both the customer and consumer of higher education Douglas, Douglas \& Barnes [5]. According to Dib and Alnazer [24] many definitions of the concept of customer satisfaction have appeared in the literature after its first introduction by Cardozo [25]. Based on a thorough literature review on customer satisfaction theory and student satisfaction in business schools, student satisfaction with business school performance will be defined as the student's positive or negative feelings experienced as a result of: 1) comparing student perceptions of actual performance of the business school with their expectations of performance; 2) questioning the fulfillment of their needs and wants; 3 ) evaluating whether or not the degree was obtained at a reasonable price.

Thus from the moment the student applies to the college of business, is accepted, and until graduation, the student is forming an internal dialog concerning the school that: 1) compares the quality level of the business school's service package elements as actually perceived with the minimum performance standards the student expects in order to be satisfied; 2) assesses the degree to which the school has prepared the student to become productive and successful in their personal and professional lives (i.e., whether they understand their field of study, have built a social network, and learned to become leaders in their field); 3) questions the perceived value of the education in terms of time, effort, and money.

The strength of the overall level of student satisfaction and consequently their impression of the business school depends on whether or not the minimum expected standards are consistently being met. In addition to personal perceptions, student expectations are also shaped by personal needs, past experiences with professors and TAs, team projects, student activities, and word-of-mouth from other students, as well as the college's various means of communication (see [5], [10], [11], [14], [15], [17], [19], [21]-[24], [26], [27]).

Research involving student satisfaction in business schools suggests that students who are consistently, or completely satisfied often become more self-confident, active participants in the educational process. Satisfied students are committed and motivated to enhance their academic performance and develop themselves by acquiring the required knowledge and skills for after graduation (see [14], [15], and, [16]).The research also suggests that student satisfaction leads to student loyalty which in turn leads to pursuing a higher degree from the same college, recommending the college to other students, and improved retention rates. These factors become a major source for the college's competitive advantage in a crowded marketplace (see [5], [10], [19], [28]-[30]). Because of these potential benefits, we saw the necessity to construct a valid student satisfaction model that best represents the underlying forces leading to overall student satisfaction at CBA.

\section{THE PROPOSED MODEL}

The professional student clubs at CBA are popular among students and have a noticeable impact and positive influence. Many students expect the clubs to play an active role in building a positive educational environment at CBA. By working with key offices and influential figures from the business community, clubs enhance academic and TA performance, and impact the quality of computer labs \& dealing rooms, the registration process, and student exchange programs. Based on our understanding of the CBA academic environment, we propose the following model, (Fig. 2). We believe satisfaction with student clubs acts as a mediator variable between satisfaction with the delivered services (exogenous variables) and overall student satisfaction (the outcome variable). When reviewing the literature on student satisfaction with business schools, no model was found that was similar to our proposed one.

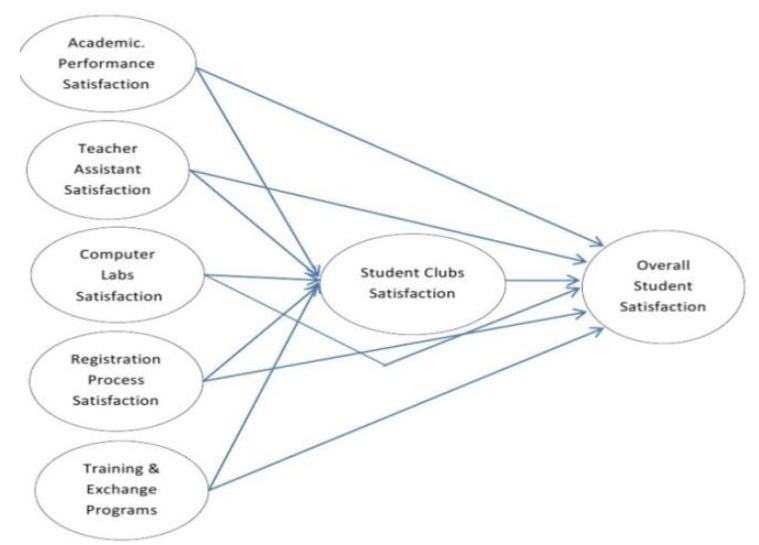

Fig. 2. Proposed student satisfaction model.

Student clubs satisfaction acts as a mediator variable between satisfaction with the delivered service (exogenous variables) and overall student satisfaction (outcome variable).

\section{A. Hypotheses}


We expect, based on our familiarity with CBA, that student satisfaction with the six dimensions of educational service will each have a positive total effect on overall student satisfaction (except for the registration process where we expect the total effect to be negative based on frequent student complaints).Additionally, satisfaction with five of these dimensions (except for the expected direct negative impact of registration) will also have a direct positive effect on satisfaction with professional student clubs. Hence, these assumptions result in the assumptions result in the following eleven alternative-hypotheses:

$H_{1}$ : Academic performance satisfaction has a positive direct effect on professional student clubs satisfaction.

$\mathrm{H}_{2}$ : Academic performance satisfaction has a positive total effect on overall student satisfaction.

$H_{3}$ : TA performance satisfaction has a direct effect on professional student clubs satisfaction

$H_{4}$ : TA performance satisfaction has a positive total effect on overall student satisfaction .

$H_{5}$ : Computer labs and dealing rooms satisfaction has a direct effect on professional student clubs satisfaction.

$H_{6}$ : Computer labs and dealing rooms satisfaction has a positive total effect on overall student satisfaction.

$H_{7}$ : Registration process satisfaction has a negative direct effect on professional student clubs satisfaction

$H_{8}$ : Registration process satisfaction has a negative total effect on overall student satisfaction.

$H_{9}$ : Training and student exchange programs satisfaction has a positive direct effect on professional student clubs satisfaction.

$H_{10}$ : Training and student exchange programs satisfaction has a positive total effect on overall student satisfaction.

$H_{11}$ : Professional student clubs satisfaction has a positive direct effect on overall student satisfaction

\section{B. Method}

\section{1) Survey design and data collection}

Measurement of perceived service quality, and in turn, student satisfaction in our structured questionnaire is a mix of both the Performance-only and Technical/Functional approaches (see [8]). The former approach "assesses service quality by simply asking customers about their level of satisfaction with various service features" (p. 38) without asking for their expectations or ideal standards, whereas in the latter, the "technical quality" of the organization output is based on the quality of its characteristics while the "functional quality is concerned with the relationships between service provider and customer such as courtesy, speed of delivery, helpfulness" (p. 38). This service package concept is based on the latter approach (see Fig. 1), and is the basis of our questionnaire and survey study. The questionnaire utilizes the elements of the service package in order to make sure that it comprehensively covers primary student-learning activities and services. These instruments were subdivided under seven headings (i.e., constructs). Six of these represent student satisfaction with the main parts of CBA's service package activities (the six dimensions of educational service). The seventh construct is related to CBA's desired outcome, overall student satisfaction.

The questionnaire focuses only on obtaining student satisfaction feedback and does not ask for either expectations or ideal performance levels with these services. Questions are worded similarly to those commonly found in previous published surveys that study student satisfaction with business school education, with modifications to fit CBA's culture as needed. At the end of the questionnaire, students were asked to answer a few demographic questions regarding gender, level of study, academic department of their major, and GPA on a scale of 0 - 4. A 5-point Likert scale was used, 1 indicating completely dissatisfied, and 5 completely satisfied.

After developing the questionnaire, a random pilot sample of 50 undergraduate students was collected to test the individual items and to check both the overall reliability and validity of the questionnaire. Some items were dropped due to either irrelevancy or to reduce the number of questions in order to maximize the explained variance during the factor analysis extraction. This resulted in a 42-item questionnaire which was randomly distributed to a total of 550 students and collected over a two month period. 490 questionnaires were returned and response rate is close to $90 \%$.

\section{2) Sample characteristics}

Gender distribution of the sample was $29 \%$ males and $71 \%$ females, a very close match to the actual gender distribution at CBA. The sample was composed of $8.6 \%$ freshmen, $16.9 \%$ sophomores, $30.3 \%$ juniors, and $43.8 \%$ seniors. Classification of the sample based on major of study was $36.3 \%$ accounting majors, $26 \%$ management and marketing majors, $19.1 \%$ public administration majors, $9.2 \%$ finance majors, 3\%economics majors, and 5.6\% included both information systems and management science majors. In terms of students' GPA, $24.6 \%$ had a GPA greater than 3.15, $25.1 \%$ had a GPA ranging between 2.73 and less than or equal to $3.15,24.4 \%$ had a GPA ranging between 2.39 and less than or equal to $2.73,25.9 \%$ of the students had a GPA less than or equal to 2.39 .

\section{RESUlts}

\section{A. Method}

Exploratory factor analysis with Verimax rotation was employed to reduce the number of questionnaire items to those most reliable and valid. Table I shows the factors of the proposed model, their reduced items, explained variances, associated factor loadings, and reliability coefficients. As shown, all reliabilities are greater than $81 \%$ ensuring a satisfactory level of internal consistency of all constructs and the explained variance is greater than $72 \%$ for all factors reflecting a high degree of construct validity (Hair, Black, Babin, \& Anderson, 2010). Moreover, the overall reliability was reasonably high (Cranach's $\alpha=90.5 \%$ ) which illustrates an acceptable level of consistency among items.

\section{B. Descriptive Statistics of Constructs}

In order to determine overall satisfaction with CBA's performance, statistical summary measures of the research constructs were computed as shown in Table II. The table shows for each research variable the minimum, the maximum, mean, standard deviation, and the p-value for testing if the average is 3 on a 5-point scale. The mean value for each 
construct was computed as a weighted average of the students' responses to the construct's most reliable and valid instruments weighted by the corresponding factor loadings.

As shown, there is overall satisfaction with CBA's performance $($ mean $=4.16, p<0.001)$ and students seem to be most satisfied with academic performance (mean $=4.14, p<$ 0.001). They are somewhat satisfied with both TA performance $($ mean $=3.81, p<0.001)$ and student club activities $($ mean $=3.63, p<0.001)$, while slightly satisfied with training \& exchanging programs $($ mean $=3.41, p<0.001)$ and with computer labs $\&$ dealing room services (mean $=3.31$, $p<0.001)$. In contrast, the students showed a degree of dissatisfaction with the registration process (mean $=2.79, p<$ $0.001)$. What follows next is an effort to further understand the students' perception of CBA's performance based on demographic characteristics of the sample.

TABLE I: EXPLAINED VARIANCE, FACTOR LOADING, AND RELIABILITY COEFFICIENT

\begin{tabular}{|c|c|c|c|c|}
\hline & Factors & $\begin{array}{l}\text { Explained } \\
\text { Variance }\end{array}$ & $\begin{array}{l}\text { Factor } \\
\text { Loading }\end{array}$ & Reliability \\
\hline & Academic Performance Satisfaction & $75.29 \%$ & & $83.5 \%$ \\
\hline 1 & Q3: Professors' Efforts to Get their Ideas Across in Class. & & .870 & \\
\hline 2 & Q4: Professors Encourage Students' Participation in Class Discussions. & & .860 & \\
\hline 3 & Q5: Professors Give Applied Examples to Illustrate Theoretical Ideas. & & .873 & \\
\hline & TA Performance Satisfaction & $76.66 \%$ & & $84.6 \%$ \\
\hline 1 & Q21: Teaching Assistants Help Students Understand Lectures. & & .884 & \\
\hline 2 & Q22: Teaching Assistants at CBA are Qualified. & & .904 & \\
\hline 3 & Q23: Teaching Assistants Attend Their Office Hours. & & .836 & \\
\hline & Computer Labs \& Dealing Rooms Satisfaction & $75.50 \%$ & & $83.8 \%$ \\
\hline 1 & Q24: Computers are Up to Date with Latest Technology. & & .862 & \\
\hline 2 & Q25: Sufficient Number of Computer Labs to Accommodate Students & & .885 & \\
\hline 3 & Q26: Lab Opening Hours are Suitable to Meet Students' Needs. & & .859 & \\
\hline & Professional Student Clubs Satisfaction & $76.73 \%$ & & $84.8 \%$ \\
\hline 1 & Q27: Student Clubs are Doing Their Best to Strengthen Student Interaction in Each Department. & & .884 & \\
\hline 2 & Q28: Student Clubs Get Enough Support to Fulfill their Goals. & & .875 & \\
\hline 3 & Q29: Students Clubs are Moderating the Relationship Between Professors and Students & & .868 & \\
\hline & Registration Process Satisfaction & $76.96 \%$ & & $84.9 \%$ \\
\hline 1 & Q30: Registration Procedures are Simple and Easy. & & .851 & \\
\hline 2 & Q31: There are Enough Courses to Accommodate Students' Needs. & & .900 & \\
\hline 3 & Q32: Various Class Timings Offered Makes Student Enrolment easy & & .880 & \\
\hline & Training Programs \& Student Exchange Satisfaction & $79.54 \%$ & & $88.5 \%$ \\
\hline 1 & Q34: Enough Training Programs are Offered Every Year. & & .899 & \\
\hline 2 & Q35: Training Programs Offered Prepare Students for the Job Market. & & .907 & \\
\hline 3 & Q36: OSTA Offers a Varity of Attractive Jobs for Graduates. & & .869 & \\
\hline 4 & Q37: The Exchange Program Center Offers a Lot of Opportunities to Study Abroad. & & .764 & \\
\hline 5 & Q38: The Exchange Program Center is Fair in whom it Selects to Study Abroad. & & .750 & \\
\hline 6 & Q39: The Exchange Program Center Selects High Quality Schools Abroad. & & .709 & \\
\hline & Overall Student Satisfaction & $72.88 \%$ & & $81.2 \%$ \\
\hline 1 & Q40: I am Satisfied of Being a Student at CBA. & & .869 & \\
\hline 2 & Q41: I am Satisfied With the Academic Department of my Major. & & .813 & \\
\hline 3 & Q42: I am Satisfied With CBA's Overall Academic Delivery Compared to Other Colleges in Kuwait. & & .738 & \\
\hline \multicolumn{2}{|c|}{ Total } & $73.483 \%$ & & $90.5 \%$ \\
\hline
\end{tabular}

\section{Effect of Demographic Characteristics on Research Variables}

\section{1) Effect of gender on student satisfaction}

While overall satisfaction was statistically identical for males and females, Table III shows that there are three significant differences between perceptions of male and female students. Male students perceive academic performance $($ mean $=4.26)$ more positively than females (mean $=4.10, p=0.015)$. They are also more satisfied (mean= 3.47 ) than female students (mean $=3.24)$ with the computer labs $\&$ dealing roomsr room services, $(p=0.013)$. Males are almost indifferent with the registration process (mean $=3.10)$, while females show a degree of dissatisfaction (mean $=2.67$, 
$p<0.001)$. Furthermore, the analysis showed no significant difference between males and females regarding the other three delivered services.

\section{2) Effect of year of study}

Table IV indicates three significant differences between students' perceptions towards the satisfaction criteria based on year in college. These include: academic performance ( $p=$ $0.001)$, computer labs \& dealing rooms $(p=0.008)$, and training \& exchanging programs services $(p=0.032)$.It is apparent that students in their senior years are less satisfied than freshmen and sophomores, although all years seem to show some degree of satisfaction with these criteria. The other criteria also showed some degree of satisfaction but with no significant differences between students' perception according to their year of study except for the registration process which showed a degree of dissatisfaction.

\begin{tabular}{|l|l|l|l|l|l|l|}
\hline Descriptive Statistics & N & Minimum & Maximum & Mean & Std. Dev. & $p$-value \\
\hline Research Variable & 485 & 1.00 & 5.00 & 4.14 & 0.750 & $0.000^{*}$ \\
\hline Academic Performance Satisfaction & 487 & 1.00 & 5.00 & 3.81 & 0.869 & $0.000^{*}$ \\
\hline TA Satisfaction & 484 & 1.00 & 5.00 & 3.31 & 0.984 & $0.000^{*}$ \\
\hline Computer Labs \& Dealing Rooms Satisfaction & 483 & 1.00 & 5.00 & 3.63 & 0.874 & $0.000^{*}$ \\
\hline Professional Student Clubs Satisfaction & 486 & 1.00 & 5.00 & 2.79 & 1.145 & $0.000^{*}$ \\
\hline Registration Process Satisfaction & 476 & 1.00 & 5.00 & 3.41 & 0.737 & $0.000^{*}$ \\
\hline Training Programs \& Student Exchange Satisfaction & 485 & 1.00 & 5.00 & 4.16 & 0.831 & $0.000^{*}$ \\
\hline Overall Student Satisfaction &
\end{tabular}

Indicates the mean is significant at $p<0.05$.

TABLE III: THE EFFECT OF GENDER ON THE LEVELS OF SATISFACTION

\begin{tabular}{|c|c|c|c|c|c|c|c|c|}
\hline Gender & $\begin{array}{l}\text { Summary } \\
\text { Statistics }\end{array}$ & $\begin{array}{l}\text { Academic } \\
\text { Performance } \\
\text { Satisfaction }\end{array}$ & $\begin{array}{l}\text { TA } \\
\text { Satisfaction }\end{array}$ & $\begin{array}{l}\text { Computer } \\
\text { Labs } \\
\text { Satisfaction }\end{array}$ & $\begin{array}{l}\text { Clubs } \\
\text { Satisfaction }\end{array}$ & $\begin{array}{l}\text { Registration } \\
\text { Satisfaction }\end{array}$ & $\begin{array}{l}\text { Training } \\
\text { Satisfaction }\end{array}$ & $\begin{array}{l}\text { Overall. } \\
\text { Satisfaction }\end{array}$ \\
\hline \multirow{3}{*}{ Male } & Mean & 4.26 & 3.81 & 3.47 & 3.49 & 3.10 & 3.43 & 4.09 \\
\hline & $N$ & 140 & 139 & 139 & 138 & 140 & 140 & 139 \\
\hline & Std. Dev. & 0.756 & 0.955 & 0.996 & 0.891 & 1.141 & 0.828 & 0.915 \\
\hline \multirow{3}{*}{ Female } & Mean & 4.10 & 3.81 & 3.24 & 3.68 & 2.67 & 3.40 & 4.19 \\
\hline & $N$ & 341 & 344 & 341 & 341 & 342 & 332 & 342 \\
\hline & Std. Dev. & 0.747 & 0.838 & 0.975 & 0.862 & 1.128 & 0.695 & 0.793 \\
\hline \multirow{3}{*}{ Total } & Mean & 4.14 & 3.81 & 3.31 & 3.63 & 2.79 & 3.41 & 4.16 \\
\hline & $N$ & 481 & 483 & 480 & 479 & 482 & 472 & 481 \\
\hline & Std. Dev. & 0.753 & 0.872 & 0.985 & 0.874 & 1.148 & 0.736 & 0.830 \\
\hline \multicolumn{2}{|l|}{$p$-value } & $.015 *$ & .702 & $.013 *$ & .063 & $.000 *$ & .580 & .447 \\
\hline
\end{tabular}

Difference is significant at $p<0.05$

TABLE IV: THE EFFECT OF YEAR OF STUDY ON THE LEVELS OF SATISFACTION

\begin{tabular}{|c|c|c|c|c|c|c|c|c|}
\hline Year of Study & $\begin{array}{l}\text { Summary } \\
\text { Statistics }\end{array}$ & $\begin{array}{l}\text { Academic } \\
\text { Performance } \\
\text { Satisfaction }\end{array}$ & $\begin{array}{l}\text { TA } \\
\text { Satisfaction }\end{array}$ & $\begin{array}{l}\text { Computer } \\
\text { Labs } \\
\text { Satisfaction }\end{array}$ & $\begin{array}{l}\text { Clubs } \\
\text { Satisfaction }\end{array}$ & $\begin{array}{l}\text { Registration } \\
\text { Satisfaction }\end{array}$ & $\begin{array}{l}\text { Training } \\
\text { Satisfaction }\end{array}$ & $\begin{array}{l}\text { Overall. } \\
\text { Satisfaction }\end{array}$ \\
\hline \multirow[t]{3}{*}{ Freshmen } & Mean & 4.34 & 3.87 & 3.70 & 3.86 & 3.09 & 3.72 & 4.29 \\
\hline & $N$ & 39 & 40 & 40 & 39 & 40 & 39 & 39 \\
\hline & Std. Dev. & 0.571 & 0.807 & 0.925 & 0.803 & 0.994 & 0.738 & 0.639 \\
\hline \multirow{3}{*}{ Sophomore } & Mean & 4.37 & 3.88 & 3.46 & 3.63 & 2.81 & 3.37 & 4.18 \\
\hline & $N$ & 81 & 81 & 79 & 80 & 81 & 78 & 80 \\
\hline & Std. Dev. & 0.700 & 0.802 & 0.901 & 0.760 & 1.141 & 0.774 & 0.897 \\
\hline \multirow{3}{*}{ Junior } & Mean & 4.06 & 3.75 & 3.33 & 3.71 & 2.71 & 3.44 & 4.16 \\
\hline & $N$ & 145 & 145 & 145 & 143 & 144 & 141 & 144 \\
\hline & Std. Dev. & 0.737 & 0.884 & 0.949 & 0.880 & 1.089 & 0.701 & 0.798 \\
\hline \multirow{2}{*}{ Senior } & Mean & 4.07 & 3.80 & 3.15 & 3.53 & 2.78 & 3.33 & 4.15 \\
\hline & Std. Dev. & 2.591 & 1.436 & 0.707 & 2.372 & 0.935 & 0.122 & 0.265 \\
\hline \multirow{3}{*}{ Total } & Mean & 4.14 & 3.81 & 3.30 & 3.63 & 2.79 & 3.40 & 4.16 \\
\hline & $N$ & 474 & 476 & 473 & 472 & 475 & 465 & 474 \\
\hline & Std. Dev. & 0.754 & 0.873 & 0.987 & 0.874 & 1.148 & 0.732 & 0.833 \\
\hline \multicolumn{2}{|l|}{$p$-value } & $0.001 *$ & 0.594 & $0.008^{*}$ & 0.124 & 0.274 & $0.032 *$ & 0.887 \\
\hline
\end{tabular}

Means the difference is significant at $p<0.05$.

\section{3) Effect of major of study}

Table V confirms overall student satisfaction with non-significant differences between majors. Satisfaction with clubs and training services, though lower, also failed to show statistically significant differences between majors. However, the other four criteria each show a significant difference in 
level based on student major. All majors are satisfied with the academic performance of professors and departments except for Management Science (MAS) majors who showed a degree of dissatisfaction (mean $=2.67$ ). All majors were fairly satisfied with the performance of TAs with MAS majors showing the lowest degree of satisfaction. Furthermore, all majors are fairly satisfied with the computer labs \&dealing rooms except for Finance majors who showed indifference $($ mean $=3.01)$ and for Economic majors who showed a degree of dissatisfaction (mean $=2.59$ ). It seems from the analysis that the registration process is a disappointment to the majority of the students, perhaps with the exception of MAS and Public Administration majors.

TABLE V: THE EFFECT OF MAJOR OF STUDY ON THE LEVELS OF SATISFACTION

\begin{tabular}{|c|c|c|c|c|c|c|c|c|c|}
\hline Major & & $\begin{array}{l}\text { Summary } \\
\text { Statistics }\end{array}$ & $\begin{array}{l}\text { Academic } \\
\text { Performance } \\
\text { Satisfaction }\end{array}$ & $\begin{array}{l}\text { TA } \\
\text { Satisfaction }\end{array}$ & $\begin{array}{l}\text { Computer } \\
\text { Labs } \\
\text { Satisfaction }\end{array}$ & $\begin{array}{l}\text { Clubs } \\
\text { Satisfaction }\end{array}$ & $\begin{array}{l}\text { Registration } \\
\text { Satisfaction }\end{array}$ & $\begin{array}{l}\text { Training } \\
\text { Satisfaction }\end{array}$ & $\begin{array}{l}\text { Overall } \\
\text { Satisfaction }\end{array}$ \\
\hline \multirow{3}{*}{$\begin{array}{l}\text { Management } \\
\text { Marketing }\end{array}$} & \multirow{3}{*}{$\&$} & Mean & 4.14 & 3.82 & 3.33 & 3.68 & 2.61 & 3.44 & 4.22 \\
\hline & & $N$ & 116 & 116 & 114 & 115 & 115 & 111 & 115 \\
\hline & & Std. Dev. & 0.693 & 0.821 & 0.973 & 0.842 & 1.011 & 0.647 & 0.832 \\
\hline \multirow{3}{*}{$\begin{array}{l}\text { Management } \\
\text { Science (MAS) }\end{array}$} & & Mean & 2.67 & 3.34 & 3.35 & 2.83 & 3.50 & 4.00 & 4.83 \\
\hline & & $N$ & 2 & 2 & 2 & 2 & 2 & 2 & 2 \\
\hline & & Std. Dev. & 0.004 & 0.484 & 0.948 & 1.179 & 1.656 & 0.935 & 0.238 \\
\hline \multirow{3}{*}{ Accounting } & & Mean & 4.09 & 3.91 & 3.35 & 3.61 & 2.65 & 3.42 & 4.21 \\
\hline & & $N$ & 160 & 161 & 159 & 159 & 160 & 158 & 161 \\
\hline & & Std. Dev. & 0.782 & 0.863 & 0.949 & 0.880 & 1.110 & 0.768 & 0.787 \\
\hline \multirow{3}{*}{\multicolumn{2}{|c|}{ Economic }} & Mean & 3.94 & 3.94 & 2.59 & 3.17 & 2.42 & 3.27 & 4.26 \\
\hline & & Std. Dev. & 16 & 17 & 17 & 16 & 16 & 16 & 16 \\
\hline & & Mean & 0.691 & 0.945 & 1.069 & 0.850 & 0.955 & 0.605 & 0.813 \\
\hline \multirow{3}{*}{\multicolumn{2}{|c|}{ Finance }} & Mean & 3.83 & 3.88 & 3.01 & 3.68 & 2.46 & 3.30 & 4.04 \\
\hline & & $N$ & 41 & 41 & 41 & 40 & 41 & 39 & 41 \\
\hline & & Std. Dev. & 1.065 & 1.042 & 1.191 & 1.065 & 1.102 & 0.817 & 0.826 \\
\hline \multirow{3}{*}{\multicolumn{2}{|c|}{ MIS }} & Mean & 3.96 & 4.14 & 3.12 & 3.56 & 2.75 & 3.39 & 4.24 \\
\hline & & $N$ & 23 & 23 & 23 & 23 & 23 & 22 & 23 \\
\hline & & Std. Dev. & 0.691 & 0.805 & 1.332 & 1.130 & 1.312 & 0.819 & 1.117 \\
\hline \multirow{3}{*}{\multicolumn{2}{|c|}{$\begin{array}{l}\text { Public } \\
\text { Administration }\end{array}$}} & Mean & 4.50 & 3.44 & 3.51 & 3.69 & 3.58 & 3.46 & 4.06 \\
\hline & & $N$ & 85 & 84 & 85 & 85 & 85 & 85 & 85 \\
\hline & & Std. Dev. & 0.524 & 0.872 & 0.851 & 0.781 & 1.083 & 0.731 & 0.843 \\
\hline \multirow{3}{*}{\multicolumn{2}{|c|}{ Total }} & Mean & 4.14 & 3.81 & 3.30 & 3.63 & 2.80 & 3.42 & 4.17 \\
\hline & & Std. Dev. & 443 & 444 & 441 & 440 & 442 & 433 & 443 \\
\hline & & Mean & 0.766 & 0.887 & 1.002 & 0.886 & 1.149 & 0.732 & 0.832 \\
\hline \multicolumn{3}{|l|}{$p$-value } & $0.000^{*}$ & $0.001^{*}$ & $0.050^{*}$ & 0.360 & $0.000 *$ & 0.605 & 0.139 \\
\hline
\end{tabular}

The difference is significant at $p<0.05$.

\section{4) Effect of GPA on student satisfaction}

Table VI shows the distribution of the criteria of satisfaction across students' academic performance measured by their GPA. As shown, students are fairly satisfied with all criteria over all levels of GPA except for the registration process where students with higher GPA show slightly higher levels of satisfaction with the process $(p=0.034)$ which is consistent with our previous findings about the students' general concern with the registration process.

\section{The Fitted Model}

After selecting the most reliable and valid indicators in Table I, we used the LISREL software to fit the data to the proposed model. Several measures of goodness of fit were calculated to assess the adequacy of the proposed model including: Normed Fit Index (NFI) $=0.95$, Non-Normed Fit Index $(\mathrm{NNFI})=0.95$, Parsimony Normed Fit Index $(\mathrm{PNFI})=$ 0.76, Comparative Fit Index (CFI) $=0.96$, Incremental Fit Index $(I F I)=0.96$, Relative Fit Index $($ RFI $)=0.94$, Critical N $(\mathrm{CN})=163.27$, Root Mean Square Residual $(\mathrm{RMR})=0.043$, Standardized RMR $=0.043$, Goodness of Fit Index $(\mathrm{GFI})=$ 0.90, and Adjusted Goodness of Fit Index (AGFI) $=0.86$. All measures of fit illustrate and verify the adequacy of the proposed model in fitting the data (see [14] and [30]). Having achieved an adequate model, it is ofinterest to study the correlation structure of its constructs.

\section{E. The Correlation Structure}

Table VII below presents the correlation between different satisfaction criteria. There are weak positive but significant correlations between satisfaction with academic performance 
and the satisfaction with: TA performance $(r=0.27)$, computer labs \& dealing rooms $(r=0.44)$, student clubs $(r=$ $0.30)$, the registration process $(r=0.40)$, training \& exchange programs $(r=0.23)$ and the overall satisfaction $(r=0.32)$. There are also weak positive but significant correlations between satisfaction with TA performance and the satisfaction with computer labs and dealing rooms $(r=0.35)$, student clubs $(r=0.42)$, the registration process $(r=0.17)$, training and exchange programs $(r=0.42)$ and the overall satisfaction $(r=0.26)$.

\begin{tabular}{|c|c|c|c|c|c|c|c|c|}
\hline GPA & $\begin{array}{l}\text { Summary } \\
\text { Statistics }\end{array}$ & $\begin{array}{l}\text { Academic } \\
\text { Performance } \\
\text { Satisfaction }\end{array}$ & $\begin{array}{l}\text { TA } \\
\text { Satisfaction }\end{array}$ & $\begin{array}{l}\text { Computer } \\
\text { Labs } \\
\text { Satisfaction }\end{array}$ & $\begin{array}{l}\text { Clubs } \\
\text { Satisfaction }\end{array}$ & $\begin{array}{l}\text { Registration } \\
\text { Satisfaction }\end{array}$ & $\begin{array}{l}\text { Training } \\
\text { Satisfaction }\end{array}$ & $\begin{array}{l}\text { Overall. } \\
\text { Satisfaction }\end{array}$ \\
\hline \multirow{3}{*}{ GPA $\leq 2.39$} & Mean & 4.10 & 3.86 & 3.39 & 3.55 & 2.55 & 3.42 & 4.18 \\
\hline & $N$ & 117 & 118 & 117 & 116 & 116 & 116 & 118 \\
\hline & Std. Dev. & 0.809 & 0.819 & 0.905 & 0.953 & 1.112 & 0.759 & 0.737 \\
\hline \multirow{3}{*}{$2.39<\mathrm{GPA} \leqslant 2.73$} & Mean & 4.06 & 3.85 & 3.30 & 3.66 & 2.70 & 3.33 & 4.21 \\
\hline & $N$ & 111 & 111 & 110 & 109 & 110 & 104 & 109 \\
\hline & Std. Dev. & 0.666 & 0.835 & 1.067 & 0.848 & 1.116 & 0.762 & 0.907 \\
\hline \multirow{3}{*}{$2.73<\mathrm{GPA} \leqslant 3.15$} & Mean & 4.19 & 3.79 & 3.24 & 3.61 & 2.91 & 3.45 & 4.12 \\
\hline & $N$ & 113 & 112 & 113 & 114 & 113 & 112 & 113 \\
\hline & Std. Dev. & 0.791 & 0.867 & 0.945 & 0.782 & 1.197 & 0.680 & 0.833 \\
\hline \multirow{3}{*}{ GPA $>3.15$} & Mean & 4.21 & 3.73 & 3.25 & 3.69 & 2.93 & 3.38 & 4.16 \\
\hline & Std. Dev. & 109 & 111 & 110 & 109 & 112 & 109 & 111 \\
\hline & Mean & 0.714 & 0.937 & 1.003 & 0.914 & 1.148 & 0.712 & 0.811 \\
\hline \multirow{3}{*}{ Total } & Mean & 4.14 & 3.81 & 3.30 & 3.62 & 2.77 & 3.40 & 4.17 \\
\hline & $N$ & 450 & 452 & 450 & 448 & 451 & 441 & 451 \\
\hline & Std. Dev. & 0.748 & 0.864 & 0.979 & 0.876 & 1.151 & 0.728 & 0.820 \\
\hline \multicolumn{2}{|l|}{$p$-value } & 0.169 & 0.853 & 0.859 & 0.441 & $0.034 *$ & 0.77 & 0.552 \\
\hline
\end{tabular}

The difference is significant at $p<0.05$.

TABLE VII: CORRELATION BETWEEN CONSTRUCTS

\begin{tabular}{|c|c|c|c|c|c|c|c|c|}
\hline Satisfaction Criteria & $\begin{array}{l}\text { Statistic } \\
\mathrm{S}\end{array}$ & $\begin{array}{l}\text { Academic } \\
\text { Performance } \\
\text { Satisfaction } \\
\end{array}$ & $\begin{array}{l}\text { TA } \\
\text { Satisfaction }\end{array}$ & $\begin{array}{l}\text { Computer } \\
\text { Labs } \\
\text { Satisfaction }\end{array}$ & $\begin{array}{l}\text { Clubs } \\
\text { Satisfaction }\end{array}$ & $\begin{array}{l}\text { Registration } \\
\text { Satisfaction }\end{array}$ & $\begin{array}{l}\text { Training } \\
\text { Satisfaction }\end{array}$ & $\begin{array}{l}\text { Overall. } \\
\text { Satisfaction }\end{array}$ \\
\hline $\begin{array}{l}\text { Academic } \\
\text { Performance } \\
\text { Satisfaction }\end{array}$ & $\begin{array}{l}\text { Corr. } \\
p \text {-value }\end{array}$ & 1 & & & & & & \\
\hline $\begin{array}{l}\text { TA } \\
\text { Satisfaction } \\
\end{array}$ & $\begin{array}{l}\text { Corr. } \\
p \text {-value }\end{array}$ & $\begin{array}{l}0.27 \\
0.000 \\
\end{array}$ & 1 & & & & & \\
\hline $\begin{array}{l}\text { Computer Labs } \\
\text { Satisfaction }\end{array}$ & $\begin{array}{l}\text { Corr. } \\
p \text {-value }\end{array}$ & $\begin{array}{l}0.44 \\
0.000\end{array}$ & $\begin{array}{l}0.35 \\
0.000\end{array}$ & 1 & & & & \\
\hline $\begin{array}{l}\text { Clubs } \\
\text { Satisfaction }\end{array}$ & $\begin{array}{l}\text { Corr. } \\
p \text {-value }\end{array}$ & $\begin{array}{l}0.30 \\
0.000\end{array}$ & $\begin{array}{l}0.42 \\
0.000\end{array}$ & $\begin{array}{l}0.50 \\
0.000\end{array}$ & 1 & & & \\
\hline $\begin{array}{l}\text { Registration } \\
\text { Satisfaction }\end{array}$ & $\begin{array}{l}\text { Corr. } \\
p \text {-value }\end{array}$ & $\begin{array}{l}0.40 \\
0.000\end{array}$ & $\begin{array}{l}0.17 \\
0.000\end{array}$ & $\begin{array}{l}0.54 \\
0.000\end{array}$ & $\begin{array}{l}0.34 \\
0.000\end{array}$ & 1 & & \\
\hline $\begin{array}{l}\text { Training } \\
\text { Satisfaction }\end{array}$ & $\begin{array}{l}\text { Corr. } \\
p \text {-value }\end{array}$ & $\begin{array}{l}0.23 \\
0.000 \\
\end{array}$ & $\begin{array}{l}0.42 \\
0.000 \\
\end{array}$ & $\begin{array}{l}0.52 \\
0.000 \\
\end{array}$ & $\begin{array}{l}0.50 \\
0.000 \\
\end{array}$ & $\begin{array}{l}0.47 \\
0.000 \\
\end{array}$ & 1 & \\
\hline Overall. Satisfaction & $\begin{array}{l}\text { Corr. } \\
p \text {-value }\end{array}$ & $\begin{array}{l}0.32 \\
0.000\end{array}$ & $\begin{array}{l}0.26 \\
0.000\end{array}$ & $\begin{array}{l}0.34 \\
0.000\end{array}$ & $\begin{array}{l}0.39 \\
0.000\end{array}$ & $\begin{array}{l}0.19 \\
0.000\end{array}$ & $\begin{array}{l}0.45 \\
0.000\end{array}$ & 1 \\
\hline
\end{tabular}

The difference is significant at $p<0.05$.

Furthermore, there is a strong positive and significant correlation between satisfaction with computer labs \& dealing rooms and the satisfaction with student clubs $(r=0.50)$, the registration process $(r=0.54)$, and training satisfaction $(r=$ $0.52)$ but a weak correlation with overall satisfaction $(r=$ 0.34).In sequel, there are weak positive and significant correlations between satisfaction with student clubs and satisfaction with the registration process $(r=0.34)$ and with the overall satisfaction $(r=0.39)$, but a strong positive correlation with training \& exchange programs satisfaction $(r$ $=0.50$ ). Additionally, there are weak positive and significant correlations between satisfaction with the registration process and with both training $\&$ exchange programs $(r=0.47)$ and the overall satisfaction $(r=0.19)$. Finally, there is weak positive and significant correlation between training \& exchange programs satisfaction and the overall satisfaction $(r$ $=0.45$ ).

\section{F. Composite Reliability and Average Explained Variance}

Reliability is a measure of internal consistency of a construct that shows how a set of items specify the latent construct. Construct reliability of $70 \%$ or more is considered acceptable ([14], [31]). Accordingly, the composite reliabilities presented in Table VIII provide sufficient evidence of the internal consistency of all constructs since they are all above $86 \%$. The variance extracted measure is 
also used to assess the adequacy of the proposed model. It reflects the overall amount of variance in the instruments accounted for by the construct. The higher the representation of the items to the latent constructs, the higher the extracted variance. It is common practice to consider $50 \%$ or higher as an adequate extracted variance for a construct (see [31], [32]) The values in Table VIII are all greater than $68 \%$. Based on the results of these two measures, it is safe to further confirm the adequacy of the proposed model and validate the items measuring each construct.

TABLE VIII: THE COMPOSITE RELIABILITY AND THE AVERAGE EXPLAINED VARIANCE

\begin{tabular}{|l|l|l|}
\hline $\begin{array}{l}\text { Satisfaction Criteria } \\
\text { (Model Constructs) }\end{array}$ & $\begin{array}{l}\text { Composite } \\
\text { Reliability }\end{array}$ & $\begin{array}{l}\text { The Average Explained } \\
\text { Variance }\end{array}$ \\
\hline Academic Performance Satisfaction & $89.90 \%$ & $71.52 \%$ \\
\hline TA Satisfaction & $88.28 \%$ & $71.64 \%$ \\
\hline Computer Labs Satisfaction & $87.74 \%$ & $70.48 \%$ \\
\hline Clubs Satisfaction & $87.87 \%$ & $70.71 \%$ \\
\hline Registration Satisfaction & $88.76 \%$ & $72.52 \%$ \\
\hline Training Satisfaction & $90.32 \%$ & $75.72 \%$ \\
\hline Overall. Satisfaction & $86.77 \%$ & $68.78 \%$ \\
\hline
\end{tabular}

TABLE IX: EVIDENCE OF DISCRIMINANT VALIDITY

\begin{tabular}{|l|l|l|l|l|l|l|l|}
\hline $\begin{array}{c}\text { Satisfaction Criteria } \\
\text { (Model Constructs) }\end{array}$ & $\begin{array}{l}\text { Academic } \\
\text { Performance } \\
\text { Satisfaction }\end{array}$ & $\begin{array}{l}\text { TA } \\
\text { Satisfaction }\end{array}$ & $\begin{array}{l}\text { Computer } \\
\text { Labs } \\
\text { Satisfaction }\end{array}$ & $\begin{array}{l}\text { Clubs } \\
\text { Satisfaction }\end{array}$ & $\begin{array}{l}\text { Registration } \\
\text { Satisfaction }\end{array}$ & $\begin{array}{l}\text { Training } \\
\text { Satisfaction }\end{array}$ & $\begin{array}{l}\text { Overall. } \\
\text { Satisfaction }\end{array}$ \\
\hline Academic Performance Satisfaction & 1 & & & & & & \\
\hline TA Satisfaction & $30.31 \%$ & 1 & & & & & \\
\hline Computer Labs Satisfaction & $49.54 \%$ & $39.77 \%$ & 1 & & & & \\
\hline Clubs Satisfaction & $34.88 \%$ & $47.69 \%$ & $56.94 \%$ & 1 & & & \\
\hline Registration Satisfaction & $44.78 \%$ & $19.20 \%$ & $61.15 \%$ & $56.61 \%$ & 1 & & \\
\hline Training Satisfaction & $25.52 \%$ & $47.04 \%$ & $58.37 \%$ & $56.13 \%$ & $52.49 \%$ & 1 & \\
\hline Overall. Satisfaction & $36.23 \%$ & $29.71 \%$ & $38.94 \%$ & $44.66 \%$ & $21.65 \%$ & $50.83 \%$ & 1 \\
\hline
\end{tabular}

TABLE X: THE PATH ANALYSIS AND the VERIFICATION OF THE RESEARCH HyPOTHESES

\begin{tabular}{|c|c|c|c|c|c|}
\hline Type of Effects & $\begin{array}{c}\text { Path } \\
\text { Coefficient }\end{array}$ & $\begin{array}{l}\text { Standard } \\
\text { Error }\end{array}$ & $t$-value & $p$-value & Significance \\
\hline \multicolumn{6}{|l|}{ Direct Effects } \\
\hline Academic $\rightarrow$ Clubs & 0.08 & 0.05 & 1.51 & 0.066 & NS \\
\hline TA $\rightarrow$ Clubs & 0.19 & 0.05 & 3.71 & $0.000^{*}$ & $\mathrm{~S}$ \\
\hline Labs $\rightarrow$ Clubs & 0.25 & 0.06 & 3.96 & $0.000^{*}$ & $\mathrm{~S}$ \\
\hline Registration $\rightarrow$ Clubs & 0.02 & 0.06 & 0.28 & 0.390 & NS \\
\hline Training $\rightarrow$ Clubs & 0.27 & 0.06 & 4.52 & $0.000^{*}$ & $\mathrm{~S}$ \\
\hline Academic $\rightarrow$ Overall & 0.22 & 0.06 & 4.04 & $0.000^{*}$ & $\mathrm{~S}$ \\
\hline TA $\rightarrow$ Overall & -0.01 & 0.05 & -0.23 & 0.591 & NS \\
\hline Labs $\rightarrow$ Overall & 0.05 & 0.07 & 0.80 & $0.000^{*}$ & NS \\
\hline Registration $\rightarrow$ Overall & -0.14 & 0.06 & -2.35 & $0.009^{*}$ & $\mathrm{~S}$ \\
\hline Training $\rightarrow$ Overall & 0.36 & 0.06 & 5.54 & $0.000^{*}$ & $\mathrm{~S}$ \\
\hline Clubs $\rightarrow$ Overall & 0.16 & 0.06 & 2.63 & $0.004^{*}$ & $\mathrm{~S}$ \\
\hline \multicolumn{6}{|l|}{ Indirect Effects } \\
\hline Academic $\rightarrow$ Overall & 0.01 & 0.01 & 1.34 & 0.090 & NS \\
\hline TA $\rightarrow$ Overall & 0.03 & 0.01 & 2.13 & $0.017 *$ & $\mathrm{~S}$ \\
\hline Labs $\rightarrow$ Overall & 0.04 & 0.02 & 3.19 & $0.001 *$ & S \\
\hline Registration $\rightarrow$ Overall & 0.00 & 0.01 & 0.28 & 0.390 & NS \\
\hline Training $\rightarrow$ Overall & 0.04 & 0.2 & 2.33 & $0.010^{*}$ & $\mathrm{~S}$ \\
\hline \multicolumn{6}{|l|}{ Total Effects } \\
\hline Academic $\rightarrow$ Overall & 0.24 & 0.06 & 4.24 & $0.000^{*}$ & $S$ \\
\hline $\mathrm{TA} \rightarrow$ Overall & 0.02 & 0.05 & 0.33 & 0.371 & NS \\
\hline Labs $\rightarrow$ Overall & 0.09 & 0.07 & 1.42 & 0.078 & NS \\
\hline Registration $\rightarrow$ Overall & -0.14 & 0.06 & -2.31 & $0.010^{*}$ & $\mathrm{~S}$ \\
\hline Training $\rightarrow$ Overall & 0.40 & 0.06 & 6.34 & $0.000^{*}$ & $\mathrm{~S}$ \\
\hline
\end{tabular}

The difference is significant at $p<0.05$. 


\section{G. Evidence of Discriminant Validity}

Discriminant validity is the extent to which latent construct $x_{1}^{1}$ discriminates from the other latent construct $x_{2}$. Farrell [33], argued for a review of discriminant validity assessment in organizational research to establish a high degree of trust and confidence in subsequent results. Although there are several measures to calculate the discriminant validity between a pair of constructs, it is safe to assess discriminant validity or lack of it between each pair of constructs using the formula

$$
D_{x_{1}, x_{2}}=\frac{r_{x_{1}, x_{2}}}{\sqrt{R_{x}^{1} \times R_{x_{2}}}}
$$

where $r_{x_{1}, x_{2}}$ is the correlation between construct $x_{1}$ and construct $x_{2}$ (from Table VIII) and $R_{x}{ }^{1}$ and $R_{x_{2}}$ are the composite reliabilities o $x_{1}$ and $x_{2}$ respectively (from Table VIII). It is common practice to consider $D_{x_{1}, x_{2}} \geq 85 \%$ as an indication of the existence of lack of discriminant validity between the constructs. From Table IX, we assure that none of our latent constructs suffer this symptom.

\section{H. The Path Analysis and the Justification of the Research Hypotheses}

Presented in Table $\mathrm{X}$ are direct, indirect, and total effects of the CBA services constructs on overall student satisfaction directly or indirectly through professional student clubs satisfaction as a mediator

\section{Direct Effects}

There is no direct effect of satisfaction with academic performance on satisfaction with the role of student clubs (path coefficient $=8 \%, p=0.066$ ), which fails to support hypothesis $H_{1}$. There is a significant positive and direct effect of the satisfaction with TA performance on the satisfaction with the role of student clubs (path coefficient $=19 \%, p<$ 0.001), which supports hypothesis $H_{3}$. Satisfaction with computer labs and dealing rooms has a significant positive direct effect on the satisfaction with the role of student clubs (path coefficient $=25 \%, p<0.001$ ), which supports $H_{5}$. Satisfaction with the registration process has no direct effect on satisfaction with the role of student clubs (path coefficient $=2 \%, p=0.390$ ), which invalidates hypothesis $H_{7}$ Finally, satisfaction with training and exchange programs has a significant positive direct effect on the satisfaction with the role of student clubs (path coefficient $=27 \%, p<0.001$ ), which confirms hypothesis $H_{9}$. Regarding the direct effect on overall student satisfaction, academic performance satisfaction shows a significant positive direct effect (path coefficient $=22 \%, p<0.001$ ), while satisfaction with TA performance has no direct effect (path coefficient $=-1 \%, p=$ 0.591). Also, satisfaction with computer labs and dealing rooms has a direct positive and significant effect on the overall satisfaction (path coefficient $=25 \%, p<0.001$ ); whereas satisfaction with the registration process has a negative direct effect (path coefficient $=-14 \%, p<0.001$ ). Finally, satisfaction with training and exchange programs has a positive and significant direct effect on overall student satisfaction (path coefficient $=35 \%, \mathrm{p}<0.001)$.

\section{J. Indirect Effects}

The indirect effects in this context substantiate the role played by the professional student clubs to enhance, as a mediator, the students' overall satisfaction. Although the indirect effects are small, they are still significant and add value to overall student satisfaction. Firstly, both satisfaction with academic performance (path coefficient $=0.01, p=$ 0.090) and satisfaction with the registration process (path coefficient $=0.00, p=0.390$ ) have no indirect effect on overall student satisfaction. However, satisfaction with TA performance (path coefficient $=3 \%, p=0.017$ ), satisfaction with computer labs and dealing rooms (path coefficient $=4 \%$, $p=0.001)$, and satisfaction with training and exchange programs ( path coefficient $=4 \%, p=0.010$ ) have positive and significant indirect effects on overall student satisfaction.

\section{K. The Total Effects}

Both satisfaction with TA performance $($ path coefficient $=$ $2 \%, p=0.371$ ) and satisfaction with computer labs and dealing rooms (path coefficient $=9 \%, p=0.0798$ ) have no total effects on overall student satisfaction which fails to support both $\mathrm{H}_{4}$ and $H_{6}$, respectively. Satisfaction with academic performance (path coefficient $=24 \%, p<0.001$ ), and satisfaction with training and student exchange programs (path coefficient $=40 \%, p<0.001$ ) each have a positive and significant total effect on overall student satisfaction which supports both hypotheses $H_{2}$ and $H_{10}$, respectively. However, students are dissatisfied with the registration process as indicated by the negative and significant total effect on overall student satisfaction (path coefficient $=-14 \%, p=0.009$ ), which supports hypothesis $H_{8}$. Finally, satisfaction with the student clubs has a positive and significant total effect on overall student satisfaction (path coefficient $=16 \%, p<$ 0.001), which supports hypothesis $H_{11}$.

\section{DISCUSSION}

Taking everything into account, our study reveals overall satisfaction of CBA students with their enrollment at the school and with its academic delivery. However, the data suggest that most of the services, with the notable exception of the academic performance of professors and academic departments, fall on the interval between neutral and satisfaction. Another noteworthy exception is student perception of the registration process, which was generally unfavorable. The degree of dissatisfaction with the registration process was expected based on complaints heard from students. Since the registration process is centralized and controlled by the Vice President for students affairs at the Kuwait University level, university colleges have little influence over the process. Given the level of dissatisfaction, the registration process definitely needs attention at both the college and university levels. Student opinion of all of the remaining services, though short of full satisfaction, indicated support of the following services in order of preference: TAs performance, professional student clubs, training and student exchange programs, and finally, computer labs and dealing rooms.

Results of the path analysis reveal that student satisfaction 
with only three out of the six services have a direct significant and positive impact on overall student satisfaction. They are: academic performance (22\%), professional student clubs $(16 \%)$, and training and student exchange programs $(35 \%)$.On the other hand, student satisfaction with computer labs and dealing rooms, and with TA performance each have a significant positive indirect effect on overall student satisfaction through the mediating construct professional student club satisfaction. Mediation is complete with a magnitude of $4 \%$ for computer labs and dealing rooms satisfaction, and of $3 \%$ for TA performance satisfaction, reflecting the role played by student clubs in enhancing overall student satisfaction.

The path analysis also reveals that the impact that training and exchange program satisfaction has on overall student satisfaction is increased by $4 \%$ due to student clubs. In contrast, student clubs don't seem to have any impact on increasing overall student satisfaction resulting from academic performance or from the registration process. Finally, the biggest impact on satisfaction with student clubs results from satisfaction with training and exchange programs $(27 \%)$, this is followed by satisfaction with computer labs and dealing rooms (25\%), and then TA performance (19\%).

What really caught our attention from the path analysis was the significant impact that professional student clubs have on increasing overall student satisfaction, although the results indicated this effect to be a modest one. This finding has lead us to believe that professional student clubs could and should play a much larger strategic role in completing the learning process at $\mathrm{CBA}$ and in assisting administration in achieving the school's learning goals. To illustrate this impact, the training service at CBA aims to accelerate employment of its graduates by providing countless training programs throughout their years of study, allowing students to gain the skills needed after graduation. The summer internship course is also an added value for students since they work at an organization that could become their future employer.

The student clubs play a parallel role in providing the same kinds of experiences. Field trips to organizations, invited talks by distinguished scholars, business men, and influential figures from government, cover a wide range of cultural, political, and scientific topics. These activities are what lead to the $4 \%$ increase in the total effect that training at $\mathrm{CBA}$ has on overall student satisfaction mentioned above. Additionally, many students spend a lot of time in the clubs studying, solving homework problems, completing TA handouts and sample exam questions which helps explain the mediating effect $(3 \%)$ that clubs play between satisfaction with TA performance and overall student satisfaction. The clubs are also equipped with computers, printers, internet, and Wi-Fi service, which allows the students to use online resources to complete homework assignments and projects without having to go to the main computer labs. This might explain the reason for the complete mediating (4\%) effect clubs have between computer labs satisfaction and overall student satisfaction. Despite club members planning out their course schedules together and discussing who to best take the various subjects with and when to take them, student clubs have not been successful in decreasing student dissatisfaction with the registration process simply because the role they are playing is that of an academic advisor. The students still need to sign up for the courses using the university registration system, wherein lies the problem.

\section{RECOMMENDATIONS}

Overall student satisfaction should be increased by improving the performance in each of the six delivered services. A cross-sectional team appointed by the Dean could determine the cause(s) behind the low levels of satisfaction reported by the students with the goal of addressing each problem area. More attention should be given to improving the performance of the professional student clubs and guiding them into playing a more vital role, that of a strategic partner with CBA's leadership team in achieving the school's learning goals. Since student clubs act as a focal point for student growth and identification with the institution they are a promising means to increase overall student satisfaction and aid in achieving learning goals. The expected role of each club in achieving the college's learning outcomes should be defined, yearly strategic goals set for them, and essential resources provided to assist them in fulfilling their responsibilities. Annual celebrations of club success would reinforce their importance and lead to further gains in learning goals.

Regarding future research, it is recommended that a study similar to the current one be conducted directed towards professors, graduate students, senior students, alumni, and potential employers. Another study could be done that considers the impact that the National Union for Kuwaiti Students has on enhancing student performance and increasing overall student satisfaction, something our current study did not address.

\section{CONCLUSION}

This study aimed to discover the strengths and weaknesses in the services delivered by CBA according to student satisfaction feedback. Results indicated that there is room for a lot of improvement in order to increase student satisfaction and achieve the college's learning goals. Results also indicated through the path analysis of a well-fitted model that professional student clubs can and should play a more strategic role in assisting the college in achieving its learning goals. One of the main reasons for establishing a business school in the first place is to develop students academically, help build character and ethical behavior, equip them with working and social skills, encourage civic responsibility, and prepare them for the market and for leading positions of society. Coursework alone will not achieve all of this; it is through the many club events organized by students that hands-on working experience is gained. It is anticipated that student learning from club activities will be positively reflected in the capstone test results, in the quality of senior projects, and in other direct measurements of the "Assurance of Learning" standard implemented at CBA.

\section{REFERENCES}

[1] S. Nataraja, A. Alharbi, and W. Idirs, "Challenges and benefits of accreditation for business colleges in the Middle East," presented at the $1^{\text {st }}$ Conference of the Consortium of Business Schools in the Gulf Cooperation Council (GCC) Region, February 16-18, 2014. 
[2] R. Zammuto, "Accreditation and the globalization of business," Academy of Management Education and Learning, vol. 7, no. 2, pp. 252-268, 2008.

[3] Y. Istileulova and D. Peljhan, "Pros and cons of international accreditation: A path of business schools towards quality seal," Economics and Business Review Journal, 2011.

[4] AACSB International - The Association to Advance Collegiate Schools of Business, "Eligibility procedures and accreditation standards for business accreditation," 2012.

[5] J. Douglas, A. Douglas, and B. Barnes, "Measuring student satisfaction at a UK university," Quality Assurance in Education, vol. 14 , no. 3, pp. 251-267, 2006.

[6] R. T. Rust and R. L. Oliver, "Service quality: Insights and managerial implications from the frontier," Service Quality: New Directions in Theory and Practice, Newbury Park, CA: Sage, 1994.

[7] C. Voss et al., Operations Management in Service Industries and Public Sector, New York: John Wiley \& Sons, 1992.

[8] J. A. Fitzsimmons and M. J. Fitzsimmons, Service Management: Operations, Strategy, Information Technology, New York: McGraw-Hill, 2008.

[9] W. E. Sasser et al., Management of Service Operations, Boston, MA: Allyn and Bacon, 1978.

[10] M. Adeola and S. Adebiyi, "Service quality, perceived value and customer satisfaction as determinant of airline choice in Nigeria," International Letters of Social and Humanistic Sciences, vol. 9, 2014.

[11] E. Seng and T. Ling, "A statistical analysis of education service quality dimensions on business school students' satisfaction," International Education Studies, vol. 6, no. 8, 2013.

[12] I. Price et al., "The impact of facilities on student choice of university," Facilities, vol. 21, no. 10, pp. 212-22, 2003.

[13] M. Abbasi, A. Malik, I. Chaudhry, and M. Imdadullah, "A study on student satisfaction in Pakistani universities: The case of Bahauddin Zakariya University," Pakistan, Asian Social Science, vol. 7, no. 7, 2011.

[14] S. Thomas, "What drives student loyalty in universities: An empirical model from India," International Business Research, vol. 4, no. 2, 2011.

[15] D. Letcher and J. Neves, "Determinants of undergraduate business student satisfaction," Research in Higher Education, vol. 6, no. 1, $1-26,2010$.

[16] E. Maddox and C. Nicholson, "The business student satisfaction inventory (BSSI): Development and validation of a global measure of student satisfaction," Developments in Business Simulation and Experiential Learning, vol. 35, pp. 101-112, 2008.

[17] O. Helgesen and E. Nesset, "Images, satisfaction and antecedents: Drivers of student loyalty? A case study of a Norwegian university college," Corporate Reputation Review, pp. 38-59, 2007.

[18] F. Husain et al., "Education service delivery and students' satisfaction: A study of private colleges in Malaysia," Global Business and Management Research, vol. 1, no. 1, 2009.

[19] A. Ijaz et al., "An empirical model of student satisfaction: Case of Pakistani public sector business schools," Journal of Quality and Technology Management, vol. 7, no. 2, pp. 91-114, 2011.

[20] M. Khuong and H. Anh, "Direct and indirect effects of customer satisfaction through product and service quality - A study of PhuNhuan jewelry stores in Ho Chi Minh City, Vietnam," Journal of Economics, Business and Management, vol. 1, no. 3, 2013.

[21] A. H. Moyazzem and R. Mahabubur, "Service quality and student satisfaction: A case study on private universities in Bangladesh," International Journal of Economics, Finance and Management Sciences, vol. 1, no. 3, pp. 128-135, 2013.

[22] J. Agbor, "The relationship between customer satisfaction and service quality: A study of three service sectors in Umeå," Umeå School of Business, Umeå, Sweden, 2011.

[23] C. N. Daniel and L. P. Berinyuy, "Using the SERVQUAL model to assess service quality and customer satisfaction. An empirical study of grocery stores in Umeå," Umeå School of Business, Umeå, Sweden, 2010.

[24] H. Dib and M. Alnazer, "The impact of service quality on student satisfaction and behavioral consequences in higher education services," International Journal of Economy, Management and Social Sciences, vol. 2, no. 6, pp. 285-290, 2013.

[25] R. Cardozo, "An experimental study of customer effort, expectation and satisfaction," Journal of Marketing Research, vol. 2, no. 3, pp. 244-249, 1965.

[26] A. Parasuraman, V. A. Zeithaml, and L. L. Berry, "A conceptual model of service quality and its implications for future research," Journal of Marketing, vol. 49, pp. 41-50, 1985.
[27] A. Parasuraman, V. A. Zeithaml, and L. L. Berry, "SERVQUAL: A multiple-item scale for measuring consumer perceptions of service quality," Journal of Retailing, vol. 64, no. 1, pp. 12-40, 1988.

[28] P. Sephton, "Modeling customer satisfaction: A panel cointegration perspective of the limited service restaurant sector," The Open Economics Journal, vol. 6, pp. 11-17, 2013.

[29] S. Al-Rahimy, "Students satisfaction with service quality in Jordanian universities," Interdisciplinary Journal of Contemporary Research in Business, vol. 4, no. 10, 2013.

[30] Z. Denga, Y. Lua, K. Weib, and J .Zhanga, "Understanding customer satisfaction and loyalty: An empirical study of mobile instant messages in China," International Journal of Information Management, vol. 30, pp. 289-300, 2010.

[31] J. F. Hair, W. C. Black, B. J. Babin, and R. E. Anderson, Multivariate Data Analysis, New York: Prentice Hall, 2010.

[32] S. Sharma, Applied Multivariate Techniques, New York: John Wiley \& Sons, Inc., 1996.

[33] A. M. Farrell, "Insufficient discriminant validity: A comment on Bove, Pervan, Beatty and Shiu," Journal of Business Research, 2009.

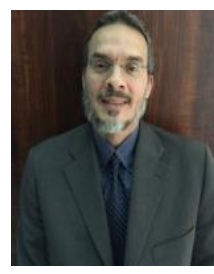

Al-Rafai Adnan was born on January 10, 1959. Dr Adnan took his Ph.D. in industrial engineering from University of Oklahoma in 1993

Currently he is a professor in the QMIS Department of Kuwait University, Kuwait. He has worked in the oil sector of Kuwait and in the government and higher education sector in Kuwait. He has several research papers in the area of operation management.

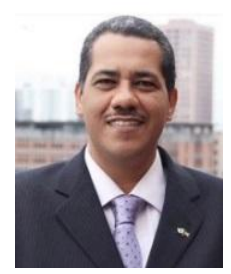

Mohammad Al Fahad was born on October 19, 1971 in Kuwait. Dr. Fahad took his Ph.D in public policy from George Mason University, U.S.A.

Currently he is the assistant dean for student affairs and heads the Business Administration Consulting Unit at the College of Business Administration, Kuwait University.

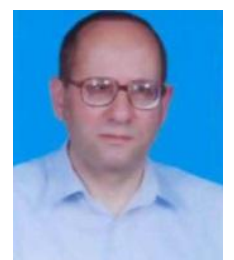

Arafa Tarek was born in Egypt on January 1, 1950 Dr. Tareq took his Ph.D. in marketing strategy, Glasgow University, UK, in 1987.

$\mathrm{He}$ is a professor in the College of Business Administration, Kuwait University, Kuwait. He has worked as a faculty member in Manafia University, Egypt. Some of his publications are: "A study of importance, availability, and suitability of privacy in designing locations for bank services from customer stand point," Journal of Commerce Ein Shames Egypt, in 2007, and "Determinants of the relationship failure between customers and clients: An applied case study," New Horizons of Commercial Studies, in 2010.

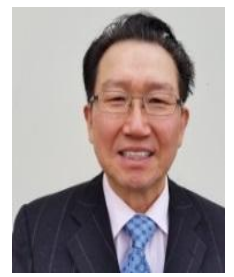

Mun Son was born in Seoul, Korea on February 5, 1950. Prof. Mun Son took his Ph.D. in statistics from Oklahoma State University, Stillwater, OK, U.S.A.

$\mathrm{He}$ is a professor in the Department of Mathematics and Statistics, University of Vermont, Burlington, VT, U.S.A. He worked with the Central Bank of Korea, as an economic research assistant in 1975-1978. Some of his published papers are: "Two stage fixed width confidence intervals for the common location parameter of several exponential distributions," Communications in Statistics, vol. 15, no. 8, pp. 2305-2322, 1986, and "Triple stage point estimation for the exponential location parameter," Annals of the Institute of Statistical Mathematics, vol. 40, no. 4, pp. 785-797, 1988, etc.

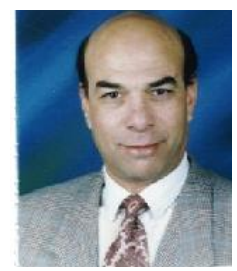

Hamdy Hosny was born in Egypt on May 30, 1948. Dr. Hosny took his Ph.D. in statistics, from Oklahoma State University, USA in 1983

$\mathrm{He}$ had worked with the University of Vermont department of mathematics and Statistics U.S.A., 1985-2005. Currently he is a professor of math/stat and the head of statistical consulting unit at the center of excellence in management in the College of Business Administration, Kuwait University. 